\title{
Environmental Pollution and Health Risks of Heavy Metals in the Soil Around a Construction Waste Landfill
}

\author{
Xiaoyan $\mathrm{Li}^{1 *}$, Shiqiang Ning ${ }^{1}$, Peng Zhang ${ }^{2}$, Weili Yang ${ }^{3}$ \\ ${ }^{1}$ School of Energy \& Environment, Zhongyuan University of Technology, Zhengzhou 451191, China \\ ${ }^{2}$ School of Electronic Information, Zhongyuan University of Technology, Zhengzhou 451191, China \\ ${ }^{3}$ Hami Polytechnic College, Hami 839001, China
}

Corresponding Author Email: 6622@zut.edu.cn

https://doi.org/10.18280/ijdne.150312

Received: 17 January 2020

Accepted: 1 April 2020

\section{Keywords:}

construction waste, heavy metals in soil, health risk, cumulative pollution

\begin{abstract}
This paper attempts to identify the content distribution of heavy metals in the soil around a construction waste landfill, and evaluate their impacts on human health. Firstly, parallel samples were collected from the soil in the study area. Then, seven heavy metals, namely, $\mathrm{Fe}, \mathrm{Cr}, \mathrm{Pb}, \mathrm{Cu}, \mathrm{Hg}, \mathrm{As}$ and $\mathrm{Cr}$, in the soil samples were detected and tested by inductively coupled plasma emission spectrometry, inductively coupled plasma mass spectrometry, and atomic fluorescence photometry, and the vertical distributions of these heavy metals were determined. After that, the cumulative risks of heavy metals in the soil were evaluated by single index method and Nemerow index method. Finally, these heavy metals were subjected to health risk analysis. The results show that the vertical distribution of $\mathrm{Cu}$ changed significantly in the soil around the landfill; the cumulative pollutions of $\mathrm{Fe}, \mathrm{Cu}$, and $\mathrm{Hg}$ in the soil reached the heavy level; the non-carcinogenic risks of $\mathrm{As}$ and $\mathrm{Cr}$ are relatively high, while $\mathrm{Cr}$ poses a carcinogenic risk to the human body. The research results provide effective data support to the site selection and operation of construction waste landfills.
\end{abstract}

\section{INTRODUCTION}

Construction waste mainly refers to the solid waste generated during the construction, demolition and decoration of buildings. The main components of construction waste are timbers, bricks, concrete fragments, scrap metals, and packaging materials [1]. China has just started to treat construction waste, showing a weak ability to utilize construction waste as a resource. About $50 \%$ of construction waste in China is not treated but landfilled in the open air [2].

Due to rain infiltration, wastewater may appear in the openair landfilled waste, and combine with the moisture of solid waste and the degradation products of residues into leachate. The physical and chemical parameters of the leachate include acidity or basicity $(\mathrm{pH})$, biological oxygen demand (BOD), chemical oxygen demand (COD), heavy metals, and ammonia nitrogen $\left(\mathrm{NH}_{4}-\mathrm{N}\right)$ [3].

The leachate generally contains four kinds of pollutants: dissolved organic matter, inorganic large components, heavy metals, and heterogeneous organic compounds [4]. There are lots of heavy metals in the leachate, due to the high heavy metal contents in construction waste [5]. The heavy metals and other harmful substances penetrate into and gradually accumulate within the soil, posing a threat to the ecoenvironment and human health.

Heavy metal pollution is mainly evaluated by index method and model method $[6,7]$. Health risk evaluation, initially for heavy metal pollution in water, has been gradually applied to evaluate heavy metal pollution in the air and the soil [8-10]. So far, there is little report on soil pollution by heavy metals in construction waste. The distribution features and pollution state of heavy metals in the soil around construction waste landfill are not yet clear.

This paper mainly explores the contents of heavy metals in the soil around a construction waste landfill, and evaluates how much these heavy metals pollute the environment and harm human body. The research findings provide a good reference for soil pollution control and health protection around construction waste landfills.

\section{METHODOLOGY}

\subsection{Study area}

The study area is a construction waste landfill on the outskirts of Xinzheng, Central China's Henan Province. Launched in 2012, the landfill is surrounded by farmlands. This area is dominated by weakly alkaline and viscous cinnamon soil, which features the leaching and deposition of calcium. Due to the accumulation of clay particles, the soil is rich in calcium carbonate, over $80 \%$ in base saturation, saturated with calcium ions, and poor in organic matter [11, 12].

The climate conditions are as follows: the annual mean temperature is $14.2^{\circ} \mathrm{C}$, the highest temperature is $42.5^{\circ} \mathrm{C}$, the lowest temperature is $-17.9^{\circ} \mathrm{C}$, the annual mean rainfall is $676.1 \mathrm{~mm}$, the annual mean evaporation is $1,476.2 \mathrm{~mm}$, the annual mean sunshine hours are $2,114.2 \mathrm{~h}$, the annual mean thunderstorm days are $19 \mathrm{~d}$, the annual mean windy days are $7 \mathrm{~d}$, and the prevailing wind direction is northwest in winter and southwest in summer. 


\subsection{Sample collection and processing}

The soil samples were collected simultaneously at the depth of $0-80 \mathrm{~cm}$ from multiple sampling points around the landfill.

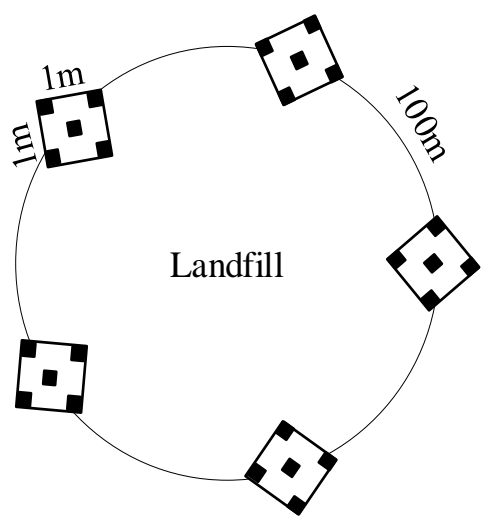

Figure 1. Sample collection

As shown in Figure 1, five $1 \mathrm{~m}^{2}$ sampling units were arranged with an interval of $100 \mathrm{~m}$ along the circumference of the landfill. Each unit was divided int five $25 \mathrm{~cm} \times 25 \mathrm{~cm}$ subunits. Then, soil columns were collected from these sub-units, and split into different layers along the soil profile from bottom to the top.

The soils in the layers of $0-5 \mathrm{~cm}, 10-15 \mathrm{~cm}, 20-25 \mathrm{~cm}, 40-$ $45 \mathrm{~cm}$ and $70-80 \mathrm{~cm}$ were retained, and screened by the quartile method, producing a $1 \mathrm{~kg}$ soil sample from each layer. Then, $0.5 \mathrm{~kg}$ of each soil sample was taken and fully mixed. The mixture was screened by the quartile method, producing a $0.5 \mathrm{~kg}$ mixed soil sample.

The remaining five $0.5 \mathrm{~kg}$ soil samples, which correspond to $0-5 \mathrm{~cm}, \quad 10-15 \mathrm{~cm}, \quad 20-25 \mathrm{~cm}, 40-45 \mathrm{~cm}$ and $70-80 \mathrm{~cm}$, respectively, were taken as test samples, and numbered as 1-1, $1-2,1-3,1-4$, and 1-5 in turn. Meanwhile, the $0.5 \mathrm{~kg}$ mixed soil sample was taken as the control sample, and numbered as 1-6.

The soil samples were transported back to the lab to measure the contents of heavy metals and organic matter. Before the measurement, each sample was dried naturally, removed of foreign objects, crushed, and passed through a $2 \mathrm{~mm}$ sieve; the powders were mixed fully, grounded, and then passed through a $0.149 \mathrm{~mm}$ nylon sieve.

\subsection{Analysis methods}

Following the automatic graphite digestion method [13], the samples were digested by a DS-72 automatic graphite digestion instrument in the following steps:

$0.5 \mathrm{~g}$ of each sample was weighted, placed into the Teflon digestion tube, and wetted with a small amount of water. Then, $10 \mathrm{~mL}$ nitric acid and $10 \mathrm{~mL}$ hydrochloride acid were added, and the tube was heated for $90 \mathrm{~min}$ at $150^{\circ} \mathrm{C}$. After the tube cooled down, $5 \mathrm{~mL}$ hydrofluoric acid and $10 \mathrm{~mL}$ perchloric acid were added, and the tube was heated for $20 \mathrm{~min}$. After the tube cooled down again, the mixture in the tube was diluted to $50 \mathrm{~mL}$ with distilled water. Then, the contents of seven metals in the sample were measured, namely, $\mathrm{Fe}, \mathrm{Cr}, \mathrm{Pb}, \mathrm{Cu}, \mathrm{Hg}$, As and $\mathrm{Cr}$.

The main instruments include an ICP-5000 full-spectrum direct-reading inductively coupled plasma emission spectrometer (incident power: 1,500W; cooling gas flow rate: $14 \mathrm{~L} / \mathrm{min}$; auxiliary gas flow rate: $1.0 \mathrm{~L} / \mathrm{min}$; atomizing gas flow rate: $1.075 \mathrm{~L} / \mathrm{min}$; peristaltic pump speed: $30 \mathrm{r} / \mathrm{min}$ ), an EXPEC 7000 inductively coupled plasma mass spectrometer, an AFS-930 atomic fluorescence photometer ( $\mathrm{Hg}$ carrier gas flow rate: $400 \mathrm{~mL} / \mathrm{min}$; As carrier gas flow rate: $300 \mathrm{~mL} / \mathrm{min}$; shielding gas flow rate: $900 \mathrm{~mL} / \mathrm{min}$; atomizer height: $10 \mathrm{~mm}$ ), and a soil organic matter content (OM) detector.

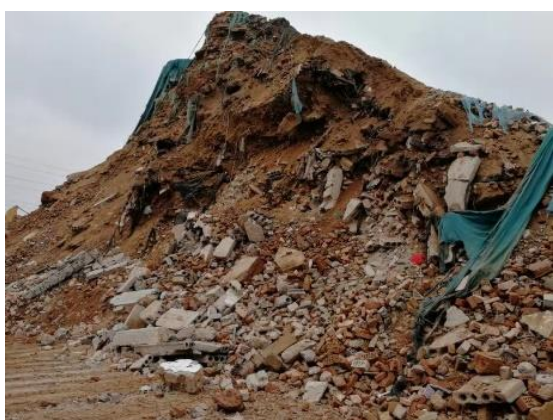

(a) The scene of the landfill

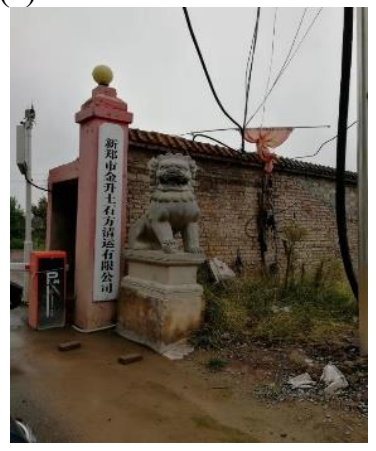

(b) Jinsheng Earthwork and Rockwork Cleaning Co., Ltd.

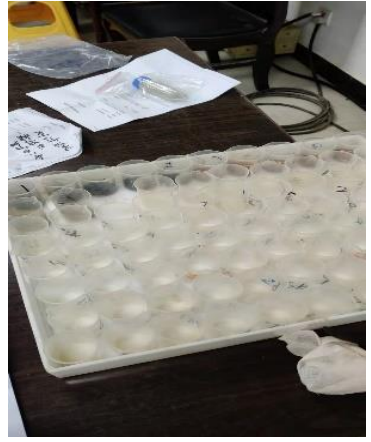

(c) Sample number

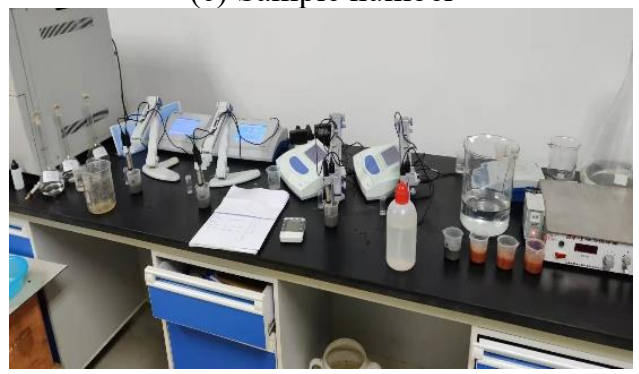

(d) Sample processing

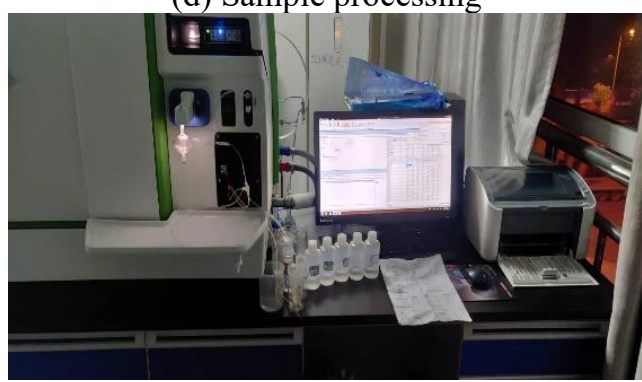

(e) Detection and analysis

Figure 2. Photos of the test site 


\section{RESULTS AND ANALYSIS}

\section{$3.1 \mathrm{pH}, \mathrm{OM}$, and heavy metal contents}

The $\mathrm{pH}, \mathrm{OM}$, and heavy metal contents of the samples collected from the soil profile were measured. The measured results are listed in Table 1 below.

\subsection{Analysis on heavy metal pollution}

\subsubsection{Vertical distribution of heavy metals in soil}

Based on the data in Table 1, the vertical distribution of heavy metal in the soil samples was simulated on Origin. The simulation results are displayed in Figure 3 . The variation of heavy metal contents in the vertical direction is illustrated in Table 2.

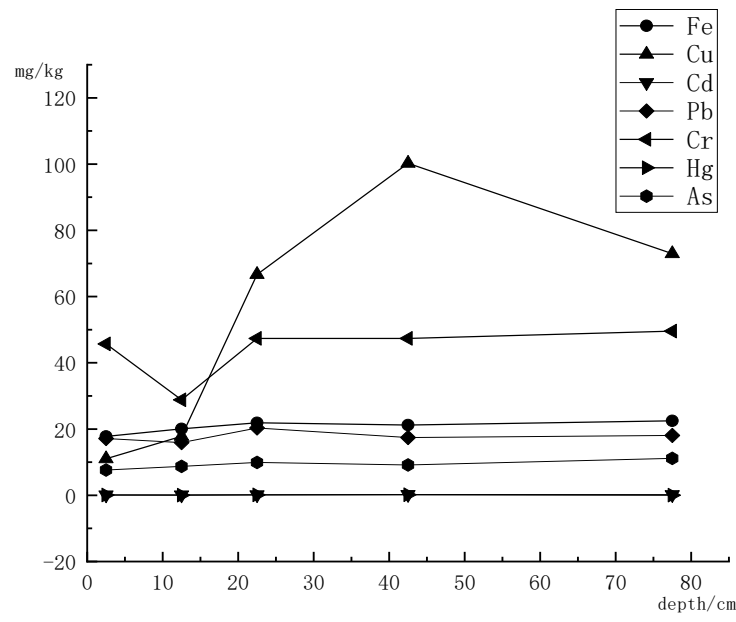

Figure 3. The vertical distribution of heavy metals
As shown in Figure 2 and Table 2, Fe content (unit: $\mathrm{g} / \mathrm{kg}$ ) was higher than the other six heavy metals. Cu content had the most significant changes in the vertical direction. The first peaks of $\mathrm{Fe}$ and $\mathrm{Pb}$ contents appeared in $20-25 \mathrm{~cm}$; this peak of $\mathrm{Pb}$ content marks the highest point of $\mathrm{Pb}$ content. The first and highest peaks of $\mathrm{Cu}, \mathrm{Cd}$, and $\mathrm{Hg}$ contents appeared in $40-45 \mathrm{~cm}$. The peaks of $\mathrm{Cr}$ and As contents appeared in $70-80 \mathrm{~cm}$. As the depth increased, $\mathrm{Fe}, \mathrm{Cr}$, and As contents continued to accumulate.

3.2.2 Correlations of heavy metal contents with $\mathrm{pH}$ and $\mathrm{OM}$ of soil

The data in Table 1 were subjected to bivariate analysis on Origin, aiming to disclose the effects of heavy metal contents on the fertility and $\mathrm{pH}$ of soil. Each pair of $\mathrm{pH}, \mathrm{OM}$, and the seven heavy metal contents underwent the Pearson correlation test, producing the similarity matrix of these parameters on the vertical profile (Table 3 )

As shown in Table $3, \mathrm{pH}$ is weakly correlated with $\mathrm{Pb}$ content (correlation coefficient: 0.224), and negatively correlated with the other parameters. The OM is significantly correlated with $\mathrm{Cd}$ and $\mathrm{Cu}$ contents. The correlation coefficients of $\mathrm{Cu}-\mathrm{Cd}, \mathrm{Fe}-\mathrm{As}$, and $\mathrm{Fe}-\mathrm{Cu}$ were large, indicating their significant correlations in the vertical direction of soil. Relatively strong correlations were observed in $\mathrm{Fe}-\mathrm{Cd}, \mathrm{Fe}-\mathrm{Cr}$, $\mathrm{Cu}-\mathrm{As}, \mathrm{Cu}-\mathrm{Cr}, \mathrm{Cu}-\mathrm{Hg}, \mathrm{Cd}-\mathrm{Cr}, \mathrm{Cd}-\mathrm{Hg}, \mathrm{Cd}-\mathrm{As}, \mathrm{Cr}-\mathrm{Hg}$, Cr-As. Extremely weak negative correlations only existed in $\mathrm{Fe}-\mathrm{Pb}$, $\mathrm{Cu}-\mathrm{Pb}, \mathrm{Pb}-\mathrm{Cr}, \mathrm{Pb}-\mathrm{Hg}$, and $\mathrm{Pb}-\mathrm{As}$, as their correlation coefficients were smaller than 0.2 . Among them, the absolute values of the correlation coefficients in $\mathrm{Cd}-\mathrm{Pb}$, $\mathrm{As}-\mathrm{Pb}$, and $\mathrm{Hg}$ As were below 0.05 , indicating that the three pairs of heavy metals are distributed independently in space. The five strongest correlations were $\mathrm{Cu}-\mathrm{Cd}>\mathrm{Fe}-\mathrm{As}>\mathrm{Fe}-\mathrm{Cu}>\mathrm{Cd}-\mathrm{Fe}>$ $\mathrm{Cu}-\mathrm{As}$.

Table 1. Measured results on $\mathrm{pH}$, organic matter content, and heavy metal contents

\begin{tabular}{|c|c|c|c|c|c|c|c|c|c|}
\hline \multirow{2}{*}{ Number } & pH & OM & $\mathbf{F e}$ & $\mathbf{C u}$ & Cd & $\mathbf{P b}$ & $\mathrm{Cr}$ & $\mathbf{H g}$ & As \\
\hline & \multicolumn{3}{|c|}{$\mathrm{g} / \mathrm{kg}$} & \multicolumn{6}{|c|}{$\mathrm{mg} / \mathrm{kg}$} \\
\hline $1-1$ & 8.73 & 3.99 & 17.78 & 11.02 & 0.10 & 17.15 & 45.72 & 0.069 & 7.62 \\
\hline $1-2$ & 8.3 & 14.2 & 20.07 & 17.82 & 0.11 & 15.91 & 28.81 & 0.033 & 8.75 \\
\hline $1-3$ & 7.77 & 35.9 & 21.91 & 66.69 & 0.18 & 20.33 & 47.35 & 0.099 & 9.93 \\
\hline $1-4$ & 7.13 & 105.6 & 21.21 & 100.26 & 0.24 & 17.46 & 47.38 & 0.158 & 9.18 \\
\hline $1-5$ & 7.73 & 44.1 & 22.49 & 72.94 & 0.19 & 18. & 49.57 & 0.027 & 11.13 \\
\hline $1-6$ & 8.78 & 24.2 & 18.1 & 13.66 & 0.12 & 22.11 & 30.48 & 0.02 & 7.96 \\
\hline
\end{tabular}

Table 2. The variation of heavy metal contents in the vertical direction

\begin{tabular}{cccccccc}
\hline Depth/cm & $\mathbf{F e}$ & $\mathbf{C u}$ & $\mathbf{C d}$ & $\mathbf{P b}$ & $\mathbf{C r}$ & $\mathbf{H g}$ & $\mathbf{A s}$ \\
\hline $0-15$ & 0.7496 & 0.2875 & 0.0949 & -0.0611 & -0.2662 & -1.3022 & 0.104 \\
$15-25$ & 0.6059 & 2.0664 & 0.9053 & 0.2175 & 0.2917 & 2.3633 & 0.1078 \\
$25-45$ & -0.2315 & 1.4196 & 0.7085 & -0.1415 & 0.0005 & 2.1367 & -0.0685 \\
$45-80$ & 0.422 & -1.1552 & -0.5977 & 0.0304 & 0.0345 & -4.7302 & 0.1792 \\
\hline
\end{tabular}

Table 3. The similarity matrix of $\mathrm{pH}, \mathrm{OM}$, and heavy metal contents

\begin{tabular}{llllllllll}
\hline & $\mathbf{p H}$ & $\mathbf{O M}$ & $\mathbf{F e}$ & $\mathbf{C u}$ & $\mathbf{C d}$ & $\mathbf{P b}$ & $\mathbf{C r}$ & $\mathbf{H g}$ & $\mathbf{A s}$ \\
\hline $\mathbf{p H}$ & 1.000 & -0.881 & -0.842 & -0.974 & -0.948 & 0.224 & -0.598 & -0.702 & -0.688 \\
$\mathbf{O M}$ & & 1.000 & 0.541 & 0.892 & 0.929 & -0.047 & 0.442 & 0.748 & 0.385 \\
$\mathbf{F e}$ & & & 1.000 & 0.825 & 0.766 & -0.128 & 0.534 & 0.286 & 0.951 \\
$\mathbf{C u}$ & & & & 1.000 & 0.989 & -0.062 & 0.694 & 0.683 & 0.711 \\
$\mathbf{C d}$ & & & & & 1.000 & 0.039 & 0.643 & 0.680 & 0.655 \\
$\mathbf{P b}$ & & & & & & 1.000 & -0.108 & -0.170 & -0.045 \\
$\mathbf{C r}$ & & & & & & & 1.000 & 0.542 & 0.536 \\
$\mathbf{H g}$ & & & & & & & & 1.000 & 0.038 \\
$\mathbf{A s}$ & & & & & & & & & 1.000 \\
\hline
\end{tabular}


3.2.3 Evaluation of cumulative pollution of heavy metals

The background values of cinnamon soil, the main soil type in the study area, were obtained as $\mathrm{Cu}: 23.65 \mathrm{mg} / \mathrm{kg}$; $\mathrm{Cd}$ : $0.0809 \mathrm{mg} / \mathrm{kg} ; \quad \mathrm{Pb}: \quad 20.3 \mathrm{mg} / \mathrm{kg} ; \quad \mathrm{Cr}: \quad 63.55 \mathrm{mg} / \mathrm{kg} ; \quad \mathrm{Hg}$ : $0.0278 \mathrm{mg} / \mathrm{kg}$; As: $10.9 \mathrm{mg} / \mathrm{kg}$; Fe: $3.045 \mathrm{~g} / \mathrm{kg}$ [14-16]. Then, the cumulative risks of these heavy metals in soil were evaluated by the single factor index method (1) and the Nemerow index method (2) [17], respectively:

$$
\begin{gathered}
p_{\mathrm{i}}=C_{\mathrm{i}} / S_{\mathrm{i}} \\
p=\left\{\left[\left(C_{\mathrm{i}} / S_{\mathrm{i}}\right)_{\max }^{2}+\left(C_{\mathrm{i}} / S_{\mathrm{i}}\right)_{\text {ave }}^{2}\right] / 2\right\}^{1 / 2}
\end{gathered}
$$

where, $P_{\mathrm{i}}$ is the cumulative index of each heavy metal in soil; $C_{\mathrm{i}}$ is the measured content of each heavy metal in soil $(\mathrm{mg} / \mathrm{kg})$; $S_{\mathrm{i}}$ is the background value of each heavy metal in cinnamon soil $(\mathrm{mg} / \mathrm{kg}) ; P$ is the Nemerow index; $\left(C_{\mathrm{i}} / S_{\mathrm{i}}\right)_{\max }$ is the maximum cumulative index of each heavy metal in soil; $\left(C_{\mathrm{i}} / S_{\mathrm{i}}\right)_{\text {ave }}$ is the mean cumulative index of each heavy metal in soil.

The $P_{\mathrm{i}}$ values and $P$ values of the seven heavy metals in the soil were calculated by formulas (1) and (2), respectively, and presented in Tables 4 and 5, respectively.

Table 4. The cumulative index of each heavy metal in soil

\begin{tabular}{cccccccc}
\hline Depth/cm & Fe & Cu & Cd & Pb & Cr & Hg & As \\
\hline $0-5$ & 5.84 & 0.47 & 1.23 & 0.85 & 0.72 & 2.50 & 0.70 \\
$10-15$ & 6.59 & 0.75 & 1.33 & 0.78 & 0.45 & 1.19 & 0.80 \\
$20-25$ & 7.20 & 2.82 & 2.23 & 1.00 & 0.75 & 3.56 & 0.91 \\
$40-45$ & 6.96 & 4.24 & 2.94 & 0.86 & 0.75 & 5.69 & 0.84 \\
$75-80$ & 7.39 & 3.08 & 2.34 & 0.89 & 0.78 & 0.96 & 1.02 \\
\hline
\end{tabular}

Table 5. The Nemerow index of each heavy metal in soil

\begin{tabular}{cccccccc}
\hline Parameter & Fe & Cu & Cd & Pb & Cr & Hg & As \\
\hline (Ci/Si)max & 7.39 & 4.24 & 2.94 & 1 & 0.78 & 5.69 & 1.02 \\
$(\mathrm{Ci} / \mathrm{Si})$ Mean & 6.79 & 2.27 & 2.01 & 0.88 & 0.69 & 2.78 & 0.86 \\
P & 7.1 & 3.4 & 2.52 & 0.94 & 0.74 & 4.48 & 0.94 \\
\hline
\end{tabular}

Based on the $P_{\mathrm{i}}$ values and $P$ values, the pollution and cumulation of heavy metals in soil samples were evaluated. The evaluation results are displayed in Table 6 . The distribution of heavy metal cumulative pollution is illustrated in Figure 4.

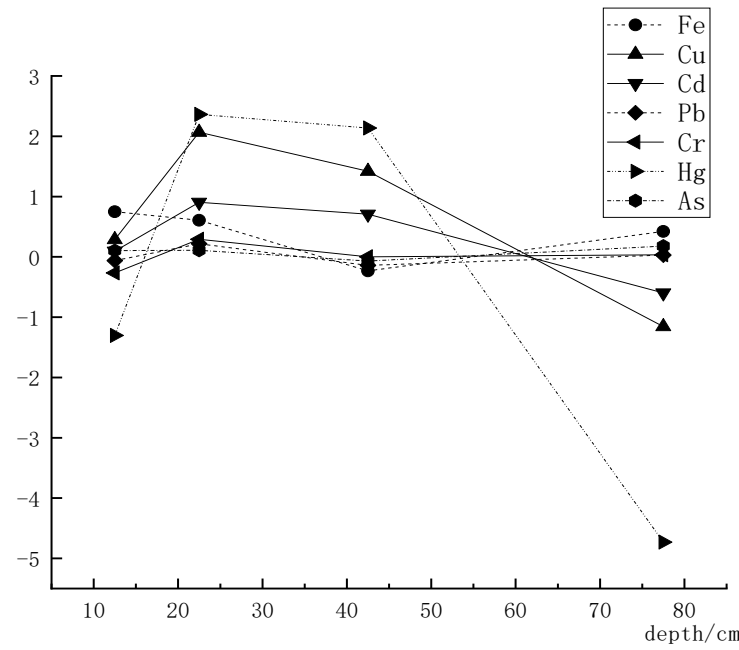

Figure 4. The distribution of heavy metal cumulative pollution

Table 6. The pollution and cumulation of heavy metals in soil samples

\begin{tabular}{cccccccc}
\hline Depth/cm & Fe & $\mathbf{C u}$ & $\mathbf{C d}$ & $\mathbf{P b}$ & $\mathbf{C r}$ & $\mathbf{H g}$ & As \\
\hline $0-5$ & Polluted & Clean & Polluted & Clean & Clean & Polluted & Clean \\
$10-15$ & Polluted & Clean & Polluted & Clean & Clean & Polluted & Clean \\
$20-25$ & Polluted & Polluted & Polluted & Polluted & Clean & Polluted & Clean \\
$40-45$ & Polluted & Polluted & Polluted & Clean & Clean & Polluted & Clean \\
$75-80$ & Polluted & Polluted & Polluted & Clean & Clean & Clean & Polluted \\
Cumulation level & Heavy & Heavy & Medium & Alert & Alert & Heavy & Alert \\
\hline
\end{tabular}

As shown in Table 3 and Figure 4, the Cr contents of all soil samples belong to clean level, but the Nemerow index of $\mathrm{Cr}$ content was 0.74 , i.e. the cumulative $\mathrm{Cr}$ pollution reached the alert level. The contents of the other heavy metals all reached the polluted level in varied degrees.

Specifically, the Pi of Fe was as high as 7.39, indicating that the soil was completely polluted by Fe in the vertical direction; the cumulative Fe pollution reached the heavy level. The cumulative contents of $\mathrm{Fe}, \mathrm{Cu}, \mathrm{Cd}$, and $\mathrm{Hg}$ were sufficient to pollute the soil. The cumulative pollutions of $\mathrm{As}$ and $\mathrm{Cr}$ reached the alert level, as their Nemerow indices were close to 1. The cumulative pollutions of $\mathrm{Cu}$ and $\mathrm{Hg}$ were the most severe at the depth of $20-45 \mathrm{~cm}$. The heavy metals could be ranked as $\mathrm{Fe}>\mathrm{Hg}>\mathrm{Cu}>\mathrm{Cd}$ in descending order of the degree of cumulative pollution. Hence, the soil around the landfill is severely polluted by heavy metals, calling for urgent repairs.

\subsection{Health risk evaluation}

3.3.1 Health risk evaluation model

According to the health risk evaluation model of United
States Environmental Protection Agency (US EPA) [18], the health risks that the heavy metals in soil bring to surrounding residents were quantified. Heavy metals could enter our body through oral intake, respiratory contact and skin intake. The average daily exposures (ADIs, $\mathrm{mg} / \mathrm{kg} \cdot \mathrm{d}$ ) of heavy metals through the three channels can be respectively calculated by:

$$
\begin{gathered}
A D I_{\text {ing }}=C \times \frac{I n g R \times E F \times E D}{B W \times A T} \times 10^{-6} \\
A D I_{\text {der }}=C \times \frac{S A \times A F \times A B S \times E F \times E D}{B W \times A T} \times 10^{-6} \\
A D I_{\text {inh }}=C \times \frac{I n h R \times E F \times E D}{P E F \times B W \times A T} \times 10^{-6}
\end{gathered}
$$

where, $A D I_{\text {ing }}, A D I_{\text {der }}$, and $A D I_{\text {ing }}$ are the ADIs of heavy metals through oral intake, respiratory contact, and skin intake, respectively $(\mathrm{mg} / \mathrm{kg} \cdot \mathrm{d}) ; C$ is heavy metal content $(\mathrm{mg} / \mathrm{kg})$; $\operatorname{Ing} R$ is the frequency of oral intake of soil $(\mathrm{mg} / \mathrm{d}) ; E F$ is the exposure frequency (d/a);ED is the exposure period (a); $A T$ is 
the average exposure time (d); $B W$ is the mean body weight $(\mathrm{kg}) ; S A$ is the exposed skin area $\left(\mathrm{cm}^{2} / \mathrm{d}\right) ; A F$ is the adhesion factor $\left(\mathrm{mg} /\left(\mathrm{cm}^{2} \cdot \mathrm{d}\right)\right) ; A B S$ is the adhesion factor of skin; InhR is the inhalation rate $\left(\mathrm{m}^{3} / \mathrm{d}\right) ; P E F$ is the dust emission factor $\left(\mathrm{m}^{3} / \mathrm{kg}\right)$.

The noncarcinogenic risk and carcinogenic risk were evaluated by formulas (6) and (7), respectively:

$$
\begin{gathered}
H I=\sum H Q_{\mathrm{i}}=\sum \frac{A D I_{\mathrm{i}}}{R f D_{\mathrm{i}}} \\
R I=\sum A D I_{\mathrm{i}} \times S F_{\mathrm{i}}
\end{gathered}
$$

where, $H I$ is the non-carcinogenic risk factor of heavy metals in the soil; $A D I_{\mathrm{i}}$ is the average daily exposure of heavy metal $\mathrm{i}$ $(\mathrm{mg} /(\mathrm{kg} \cdot \mathrm{d})) ; R f D_{\mathrm{i}}$ is the reference dose of chronic toxicity of heavy metal i $(\mathrm{kg} /(\mathrm{mg} \cdot \mathrm{d})) ; R I$ is the carcinogenic risk factor of heavy metals in the soil; $S F_{\mathrm{i}}$ is the carcinogenic slope factor of heavy metal i $((\mathrm{mg} / \mathrm{kg}) / \mathrm{d})$.

\subsubsection{Health risk evaluation}

The values of model parameters were selected referring to materials like the Exposure Factors Handbook of Chinese Population [19, 20] (Table 7). The reference doses of heavy metal toxicity and carcinogenic slope factor were also determined based on these materials. Then, the health risks of carcinogenic heavy metals $(\mathrm{Pb}, \mathrm{Cd}, \mathrm{Cr}$, and $\mathrm{As})$ and two noncarcinogenic heavy metals $(\mathrm{Cu}$ and $\mathrm{Hg}$ ) were evaluated. The evaluation results of non-carcinogenic risks and carcinogenic risks are listed in Table 8, and the health risks of all seven heavy metals are presented in Table 9.

Table 7. The parameter values of health risk evaluation

\begin{tabular}{cccc}
\hline Parameter & Sign & Unit & Value \\
\hline Heavy metal content & $\mathrm{C}$ & $\mathrm{mg} / \mathrm{kg}$ & Mean measured value \\
Frequency of oral intake of soil & $\mathrm{IngR}$ & $\mathrm{mg} / \mathrm{d}$ & 50 \\
Inhalation rat & $\mathrm{InhR}$ & $\mathrm{m} / \mathrm{d}$ & 12.85 \\
Exposure frequency & $\mathrm{EF}$ & $\mathrm{d} / \mathrm{a}$ & 345 \\
Exposure period & $\mathrm{ED}$ & $\mathrm{a}$ & 30 \\
Average exposure time & $\mathrm{AT}$ & $\mathrm{d}$ & $30 * 365$ (noncarcinogenic) \\
& & & $70 * 365$ (carcinogenic) \\
Mean body weight & $\mathrm{BW}$ & $\mathrm{kg}$ & 62.8 \\
Exposed skin area & $\mathrm{SA}$ & $\mathrm{cm}^{2} / \mathrm{d}$ & 0.153 \\
Dust emission factor & $\mathrm{PEF}$ & $\mathrm{m}^{3} / \mathrm{kg}$ & $1.36 \mathrm{E}-09$ \\
Adhesion factor & $\mathrm{AF}$ & $\mathrm{mg} /\left(\mathrm{cm}{ }^{2} \cdot \mathrm{d}\right)$ & 0.49 \\
Adhesion factor of skin & $\mathrm{ABS}$ & - & 0.001 \\
Reference doses of heavy metal toxicity & $\mathrm{RfD}$ & $\mathrm{kg} /(\mathrm{mg} \cdot \mathrm{d})$ & {$[23-24]$} \\
Carcinogenic slope factor & $\mathrm{SF}$ & $(\mathrm{mg} / \mathrm{kg}) / \mathrm{d}$ & {$[24]$} \\
\hline
\end{tabular}

Table 8. The evaluation results of noncarcinogenic risk and carcinogenic risk

\begin{tabular}{ccccccc}
\hline Parameter & $\mathbf{C u}$ & $\mathbf{H g}$ & $\mathbf{P b}$ & $\mathbf{C d}$ & $\mathbf{C r}$ & $\mathbf{A s}$ \\
\hline HI & $1.01 \times 10^{-3}$ & $1.93 \times 10^{-4}$ & $3.83 \times 10^{-3}$ & $1.20 \times 10^{-4}$ & $1.10 \times 10^{-2}$ & $2.34 \times 10^{-2}$ \\
RI & & & $1.14 \times 10^{-7}$ & $4.56 \times 10^{-8}$ & $1.35 \times 10^{-3}$ & $1.05 \times 10^{-5}$ \\
\hline
\end{tabular}

Table 9. The health risks of heavy metals

\begin{tabular}{cccccccc}
\hline Parameter & $\mathbf{F e}$ & $\mathbf{C u}$ & $\mathbf{H g}$ & $\mathbf{P b}$ & $\mathbf{C d}$ & $\mathbf{C r}$ & $\mathbf{A s}$ \\
\hline Average & 20.69 & 53.75 & 0.077 & 17.79 & 0.16 & 43.77 & 9.32 \\
ADI ing & $1.56 \mathrm{E}-05$ & $4.04 \mathrm{E}-05$ & $5.79 \mathrm{E}-08$ & $1.34 \mathrm{E}-05$ & $1.20 \mathrm{E}-07$ & $3.29 \mathrm{E}-05$ & $7.01 \mathrm{E}-06$ \\
ADI dermal & $2.33 \mathrm{E}-11$ & $6.07 \mathrm{E}-11$ & $8.69 \mathrm{E}-14$ & $2.01 \mathrm{E}-11$ & $1.81 \mathrm{E}-13$ & $4.94 \mathrm{E}-11$ & $1.05 \mathrm{E}-11$ \\
ADI inh & $2.33 \mathrm{E}-11$ & $6.07 \mathrm{E}-11$ & $8.69 \mathrm{E}-14$ & $2.01 \mathrm{E}-11$ & $1.81 \mathrm{E}-13$ & $4.94 \mathrm{E}-11$ & $1.05 \mathrm{E}-11$ \\
ADI & $1.56 \mathrm{E}-05$ & $4.04 \mathrm{E}-05$ & $5.79 \mathrm{E}-08$ & $1.34 \mathrm{E}-05$ & $1.20 \mathrm{E}-07$ & $3.29 \mathrm{E}-05$ & $7.01 \mathrm{E}-06$ \\
RfD oral & & 0.04 & 0.0003 & 0.0035 & 0.001 & 0.003 & 0.0003 \\
HI & & $1.01 \mathrm{E}-03$ & $1.93 \mathrm{E}-04$ & $3.83 \mathrm{E}-03$ & $1.20 \mathrm{E}-04$ & $1.10 \mathrm{E}-02$ & $2.34 \mathrm{E}-02$ \\
SF & & & & 0.0085 & 0.38 & 41 & 1.5 \\
RI & & & & $1.14 \mathrm{E}-07$ & $4.58 \mathrm{E}-08$ & $1.35 \mathrm{E}-03$ & $1.05 \mathrm{E}-05$ \\
\hline
\end{tabular}

From formulas (6) and (7), the total non-carcinogenic risk was 0.00395 , and the total carcinogenic risk was 0.000136 . Both were beyond the acceptable risk range of $10^{-6}-10^{-4}$, a indicating the presence of health risks. Besides, $\mathrm{ADI}_{\text {dermal }}$ and $\mathrm{ADI}_{\text {inh }}$ were both in the order of $10^{-11}$. The oral intake $\mathrm{ADI}_{\text {ing }}$ is the main source of the ADI of heavy metals.

The non-carcinogenic risk factors of $\mathrm{Cu}, \mathrm{Pb}, \mathrm{Cr}$, and $\mathrm{As}$ and the non-carcinogenic risk factor of $\mathrm{Cr}$ were above the acceptable range, indicating that the heavy metals $\mathrm{Cu}, \mathrm{Pb}, \mathrm{Cr}$, and As in the soil pose a non-carcinogenic risk to the human body. Among them, the non-carcinogenic risks of As and $\mathrm{Cr}$ are relatively high. Meanwhile, $\mathrm{Cr}$ has a carcinogenic risk to the human body.
The Fe was not covered in the health risk evaluation, for the lack of effective data on the reference dose of its toxicity. There are certain limitations on the selection of exposure parameters.

\section{CONCLUSIONS}

(1) In the soil around the landfill, peak points were observed in the vertical distribution of all seven heavy metals. The distribution of $\mathrm{Cu}$ changed more significantly than that of any other heavy metal. In terms of vertical distribution, obvious 
synergy effects were observed between $\mathrm{Cu}-\mathrm{Cd}$, Fe-As, and Fe$\mathrm{Cu}$.

(2) In the soil of the study area, $\mathrm{Fe}, \mathrm{Cu}, \mathrm{Hg}, \mathrm{Pb}, \mathrm{Cd}$, and $\mathrm{As}$ contents reached the polluted level. The cumulative pollutions of $\mathrm{Fe}, \mathrm{Hg}$, and $\mathrm{Cu}$ were on the heavy level. This means the soil in the study area has been severely polluted by heavy metals.

(3) The heavy metals in the soil pose carcinogenic and noncarcinogenic risks to the human body. Among them, the noncarcinogenic risks of $\mathrm{As}$ and $\mathrm{Cr}$ are relatively high. Meanwhile, $\mathrm{Cr}$ has a carcinogenic risk to the human body. The landfill should be relocated, and the polluted soil should be repaired.

\section{ACKNOWLEDGMENT}

This work is supported by Industry-Academic Cooperation Collaborative Education Project of Ministry of Education (201902047078); Henan National Coal Mine Safety Administration Project (HN19-61); Industry-Academic Cooperation Collaborative Education Project of Ministry of Education (201902047063); Key Research Project Funding Project of higher education in Henan Province (19A440012); Industry-Academic Cooperation Collaborative Education Project of Ministry of Education (201901040049); Henan Education Science "Thirteenth Five-Year Plan" General Project (2019)-JKGHYB-0099; Employment and Entrepreneurship Project of Colleges and Technical Colleges in the Department of Education of Henan Province (Provincial JYB2019020); Key Project of Vocational Education Research Project of Xinjiang Education Department (XJZJKT2019Z02).

\section{REFERENCES}

[1] Su, Y. (2020). Multi-agent evolutionary game in the recycling utilization of construction waste. Science of The Total Environment, 738: 139826. https://doi.org/10.1016/j.scitotenv.2020.139826

[2] Dilbas, H., Çakır, Ö. (2020). Influence of basalt fiber on physical and mechanical properties of treated recycled aggregate concrete. Construction and Building Materials, 254:

119216 https://doi.org/10.1016/j.conbuildmat.2020.119216

[3] Calace, N., Liberatori, A., Petronio, B.M., Pietroletti, M. (2001). Characteristics of different molecular weight fractions of organic matter in landfill leachate and their role in soil sorption of heavy metals. Environmental pollution, 113(3): 331-339. https://doi.org/10.1016/S0269-7491(00)00186-X

[4] Luo, H., Zeng, Y., Cheng, Y., He, D., Pan, X. (2020). Recent advances in municipal landfill leachate: A review focusing on its characteristics, treatment, and toxicity assessment. Science of The Total Environment, 703: 135468. https://doi.org/10.1016/j.scitotenv.2019.135468

[5] Somasundaram, S., Jeon, T.W., Kang, Y.Y., Kim, W.I., Jeong, S.K., Kim, Y.J., Yeon, J.M., Shin, S.K. (2015). Characterization of wastes from construction and demolition sector. Environmental monitoring and assessment, $\quad 187(1)$ : 4200 https://doi.org/10.1007/s10661-014-4200-0

[6] Vareda, J.P., Valente, A.J., Durães, L. (2019). Assessment of heavy metal pollution from anthropogenic activities and remediation strategies: A review. Journal of environmental management, 246: 101-118. https://doi.org/10.1016/j.jenvman.2019.05.126

[7] Maués, L.M.F., do Nascimento, B.D.M.O., Lu, W., Xue, F. (2020). Estimating construction waste generation in residential buildings: A fuzzy set theory approach in the Brazilian Amazon. Journal of Cleaner Production, 121779. https://doi.org/10.1016/j.jclepro.2020.121779

[8] Waskow, R.P., dos Santos, V.L., Ambrós, W.M., Sampaio, C.H., Passuello, A., Tubino, R.M. (2020). Optimization and dust emissions analysis of the air jigging technology applied to the recycling of construction and demolition waste. Journal of Environmental Management, 266: 110614. https://doi.org/10.1016/j.jenvman.2020.110614

[9] Hu, B., Shao, S., Ni, H., Fu, Z., Hu, L., Zhou, Y., Min, X., She, S., Chen, S., Huang, M., Zhou, L., Li, Y., Shi, Z. (2020). Current status, spatial features, health risks, and potential driving factors of soil heavy metal pollution in China at province level. Environmental Pollution, 114961. https://doi.org/10.1016/j.envpol.2020.114961

[10] Jalali, M., Karimi Mojahed, J. (2020). Assessment of the health risks of heavy metals in soils and vegetables from greenhouse production systems in Iran. International Journal of Phytoremediation, 22(8): 834-848. https://doi.org/10.1080/15226514.2020.1715917

[11] Nriagu, J.O., Pacyna, J.M. (1988). Quantitative assessment of worldwide contamination of air, water and soils by trace metals. Nature, 333(6169): 134-139. https://doi.org/10.1038/333134a0

[12] Saldaña, A., Ibáñez, J.J., Zinck, J.A. (2011). Soilscape analysis at different scales using pattern indices in the Jarama-Henares interfluve and Henares River valley, Central Spain. Geomorphology, 135(3-4): 284-294. https://doi.org/10.1016/j.geomorph.2011.02.016

[13] Charlesworth, S., Everett, M., McCarthy, R., Ordonez, A., De Miguel, E. (2003). A comparative study of heavy metal concentration and distribution in deposited street dusts in a large and a small urban area: Birmingham and Coventry, West Midlands, UK. Environment International, 29(5): 563-573. https://doi.org/10.1016/S0160-4120(03)00015-1

[14] China Environmental Monitoring Station. (1990). Background values of soil elements in China. Beijing: China Environmental Science Press.

[15] Shao, F.S., Zhou, H.Y. (1998). Soil environmental background values of main elements in Henan Province. Henan agriculture, (10): 28.

[16] Chen, Y., Ma, J., Miao, C., Ruan, X. (2020). Occurrence and environmental impact of industrial agglomeration on regional soil heavy metalloid accumulation: A case study of the Zhengzhou Economic and Technological Development Zone (ZETZ), China. Journal of Cleaner Production, 245: 118676. https://doi.org/10.1016/j.jclepro.2019.118676

[17] Lee, H., Lee, Y. (2020). Environmental pollution from heavy metals in soil and stream near an abandoned mine in Korea. Toxicology and Environmental Health Sciences, 12: 137-148. https://doi.org/10.1007/s13530020-00050-w

[18] US EPA, Office of Solid Waste Emergency Response. (2009). Waste and cleanup risk assessment. Risk Assessment Guidance for Superfund (RAGS), Volume I: Human Health Evaluation Manual, Part E: Supplemental Guidance for Dermal Risk Assessment, Interim. 
[19] Ministry of Environmental Protection. (2013). Handbook of human exposure parameters in China (Adult volume, Children volume). Beijing: China Environment Publishing House.
[20] Chen, H., Teng, Y., Lu, S., Wang, Y., Wang, J. (2015). Contamination features and health risk of soil heavy metals in China. Science of the total environment, 512: 143-153. https://doi.org/10.1016/j.scitotenv.2015.01.025 